\section{Analysing the Possible Physical Tmpact of Flood Disasters on Cultural Heritage in Ayutthaya, Thailand}

\author{
Wittaya Daungthima ${ }^{a^{*}}$, Kazunori Hokao ${ }^{b}$
}

${ }^{a}$ Ph.D Candidate, Graduate School of Science and Engineering, Saga University, Saga city, 840-0o27,JAPAN

${ }^{b}$ Professor, Ph.D, Graduate School of Science and Engineering, Saga University, Saga city, 840-0027, JAPAN.

Received: April 1, 2013/ Accepted: May 24, 2013

\begin{abstract}
This article aims to assess the possible physical impact of flood disaster on historical monument sites (HMS). It was found that there are six crucial disaster vulnerability factors. Of these, there are two most important factors for analysing the possible physical impact of flood, which are topography and the distance from the river. In this study 489 HMS were assessed, 294 of these were assessed as possibly being damaged by flood with extremely high, very high or high vulnerability. The field survey assessed 84 HMS as being damaged by the previous 2011 flood. The approach was based on previous studies and the application of Geographic information system(GIS) techniques and on Spatial Multicriteria Evaluation (SMCE) for identifying the disaster vulnerability areas and the priorities for HMS conservation. For the present study, this adopted approach was chosen because it allows non-experts in the field of urban planning and urban architecture to perform surveys on the steps for conservation of HMS in a data scarce environment. Moreover, the results of GIS can be verified with the field survey to deliver priorities of intervention based on the vulnerability of the HMS assets. This study also evaluates the risk factors for integrating hazard risk aspects of cultural heritage sites into conservation plans.
\end{abstract}

Keywords: Ayutthaya flood, Conservation, Cultural heritage, flood disaster, historical monument site, physical impact.

\begin{tabular}{|lll|}
\hline Abbreviations: \\
\hline HMS & $:$ & Historical Monument Sites \\
GIS & $:$ & Geographic information system \\
SMCE & $:$ & Spatial Multi-criteria Evaluation \\
MCDA & $:$ & Multi-criteria Decision Analysis \\
\hline
\end{tabular}

\section{Introduction}

World Heritage properties are important for national and community pride and for social cohesion. Under the World Heritage Convention, the States / Parties sign up to the obligation of preserving World Heritage properties for future generations.
Therefore managers of these properties are responsible for protecting their outstanding universal value. Disasters do happen, therefore it is best to be prepared to manage these unavoidable events [1].

Thailand is regarded as highly vulnerable to natural disasters caused by hydro-meteorological phenomena (floods, landslides, storms, droughts, etc.). Moreover it is also ranked as the seventh most flood prone country in the world. Floods occur almost annually, and they are by far the most devastating disaster in the country. Official statistics from2002-2008 show that the country floods on average approximately 10 times per year [2-3]. Ayutthaya is a province in the middle of Thailand, located $75 \mathrm{~km}$. from Bangkok, the capital city of Thailand.

Ayutthaya has a long history of flood cycles with seasonal variance. The basin area is flat at an average elevation of 1 to 2 meters above the mean sea level with certain spots where the elevation down to the sea level due to land subsidence. Ayutthaya's river flooding problems have occurred for a long time. In the past, the local people solved this problem by digging canals. We can still find many canals and water gates today at most of rivers around and inside the Ayutthaya Island [4]. As situations have changed, canal digging is no longer appropriate as city flood protection. The flood in 2011, has resulted in physical, economic, social and environmental damage [5]. The important historical monument sites (HMS) of Ayutthaya were also affected and damaged.

\section{Risk and vulnerability}

Definitions of risk and damage used in research vary with the applications for which they are used. Their basis lies in a commonsense understanding of the concept of risk, such as the notion that the risk associated with some particular hazard lies in the consequences of that hazard, and increases with both the probability and severity of the hazard. This study investigates the risk of flood damage, and measures risk factors of the consequent physical direct damage to the HMS in Ayutthaya, Thailand.

\subsection{Defining vulnerability}

General definitions of vulnerability and related terms are as follows [6]:

Vulnerability $=$ Exposure + Resistance + Resilience

Exposure: at risk property and population; Resistance: measures taken to prevent, avoid or reduce damage; Resilience: capability to recover to the prior state or achieve a desired post-disaster state.

\subsection{Assessing impacts and measuring physical vulnerability}

Measuring physical vulnerability is increasingly seen as an effective step towards risk reduction and the promotion of a culture of disaster resilience [7]. The Hyogo Framework for Action also stresses the need to develop indicators of vulnerability as a key activity, and underlines the fact that the impacts of disasters on social, economic and environmental conditions must be examined through such indicators. Since vulnerability is multidimensional, dynamic in time, scale-dependent and site-specific, different indicators are selected in different vulnerability assessments studies. 


\subsection{Determinants of the flood risk}

This study determines factors of flood risk by adapting from components of disaster risk (following Shook [8]): disaster determinants are hazard, vulnerability and manageability. Flood risk is the possibility of losses, in life assets and other consequences that impact on human society. Saltbones [9] further refers to the components which influence the amount of risk, including: exposure, hazard, vulnerability and manageability [810]. The determinants of flood risk are determined not only by vulnerability but also by characteristics and coping capacity to flood exposure. Therefore, the risk of flood is based on three crucial elements which are related as shown in figure 1.

$$
\text { Flood Risk }=\frac{\text { Vulnerability } \mathrm{x} \text { Characteristic }}{\text { Coping capacity }}
$$

Figure 1 The formula of flood risk; sources: adapted from Shook [8], Saltbones [9] and Mongkonkerd [10]

Residents cannot avoid flood problems when they are in flood risk areas [10]. The best ways to reduce flood risk are reducing vulnerability and increasing coping capacity, which is a core common component of flood risk management. Figure 2 and Figure 3; show the elements of flood risk which depend on vulnerability, frequency of damage, the ability of local people to cope with flood as follows:

2.3.1 Vulnerability refers to circumstances of a community or asset that make it susceptible to the damaging effects of a flood. There are many aspects of vulnerability, arising from various physical, social, economic, and environmental factors. Examples may include construction of buildings, inadequate protection of assets, lack of information and awareness $[6,11]$.

2.3.2 Characteristic refers to natural disaster occurrence, frequency of damage, duration and maximum water level

2.3.3 Coping capacity is the ability of people in the community to face and manage the flood using available skills and resources. The capacity to cope requires continuing awareness, resources and good management, both in normal times as well as during crises or adverse conditions [11].

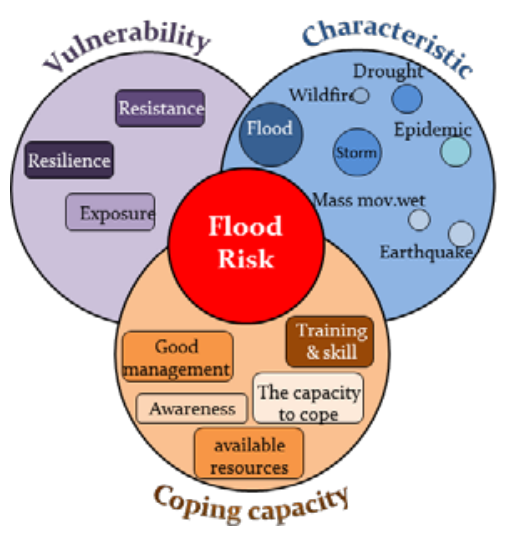

Figure 2 The components of flood risk; (authors' original image, 2013)

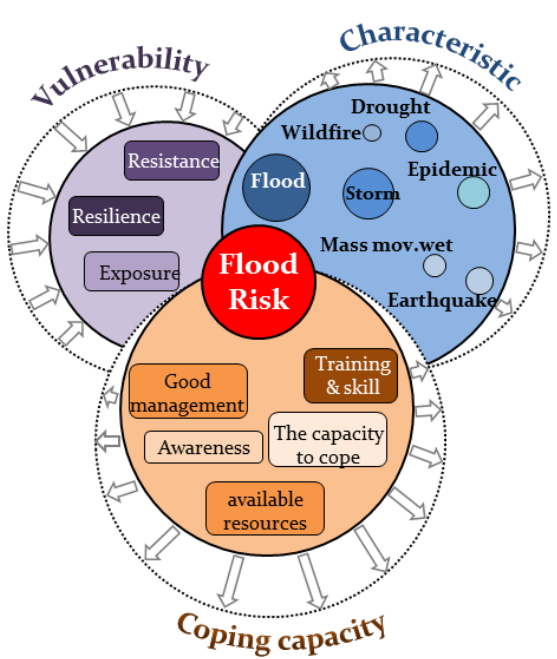

Figure 3 The reduction of flood risk; (authors' original image, 2013)

\subsection{Disaster vulnerability factors}

Reviews of disaster vulnerability factors, found that the most crucial factors may be organised as six groups of factors which are: topography, slope, density of building, distance from the river, drainage system \& soil type, and distance to road. Topography refers to current elevation and surface water flow paths [12-16]. Slope refers to upstream source of flooding, flood susceptibility and overflow sensibility [13, 15-16]. Density of building refers to land value per floor space and land use [12, 14].The distance from the river refers to area flooding risk [12, 14-16]. Drainage system \& soil refer to vulnerable community and critical, soil erodibility, soil drainage, soil moisture, soil scape in fragile environmental balance and soil composition [12-15]. Distance to road refers to distance of historical sites to road [12, 15-16].

Table 1 The disaster vulnerability factors

\begin{tabular}{ll}
\hline Factors & Detail of factors \\
\hline Topography & Current elevation \\
Slope & Surface water flow paths \\
& Upstream source of flooding \\
& Flood susceptibility \\
& Overflow sensibility \\
Density of building & Land value per floor space \\
& Land use \\
Distance from & Area at risk from flooding \\
the river & \\
Drainage system & Vulnerable community and critical \\
\& Soil & infrastructure \\
& Soil erodibility \\
& Soil drainage \\
& Soil moisture \\
& Soil scape in fragile environmental \\
& balance \\
& Soil composition \\
Distance to road & Distance of historical site to road \\
\hline
\end{tabular}

\section{Study area}

The Historic City of Ayutthaya, founded in ca.1350, was registered as a world heritage site on December 13, 1991 by the Wold Heritage Property as meeting the following criteria: it is a testament to the culture or civilization that has emerged in the present, considered as important to the history of race, of Ayutthaya and of Thailand [17].

The Historic City of Ayutthaya is located on an island of the Chao Phraya River basin surrounding with three major rivers, Chao Phraya river in the west and the south, Lopburi river in the north and Pasak river in the north and the east[9]. Consequently, 
the Ayutthaya city always floods in the high water season of each year. It is evident that the heaviest floods in Ayutthaya are caused by the northern floods, which result from the changes in climate.

\subsection{Distribution of Historical Monument Sites}

The Fine Arts Department has 136 historical monument sites and listed 411 historical monument sites altogether from 1935 until the present [18]. The total study area covers 102.97 square kilometers. 199 historical sites are within Ayutthaya Island and 290 are around Ayutthaya Island. The study area of HMS was divided into six zones, the most important area which has the best physical development and atmosphere is (1) the Nucleus Zone, while (2) is an area with less importance in the City Island and the other four of six areas are the Buffer Zone outside the city Island. The distribution of the 489 HMS in the study area (115 registered HMS and 374 listed HMS) is shown in Table 2. The distribution of HMS coordinated by Global Positioning System (GPS) was used to take coordinates of locations of HMS, as shown in Figure 4.

Table 2 Distribution of Historical Monument Sites in Ayutthaya

\begin{tabular}{lcc}
\hline Historical monument sites & Registered & Listed \\
\hline Zone 1 & 30 & 75 \\
Zone 2 & 30 & 64 \\
Zone 3 & 18 & 90 \\
Zone 4 & 5 & 26 \\
Zone 5 & 27 & 79 \\
Zone 6 & 5 & 40 \\
Total & 115 & 374 \\
\end{tabular}

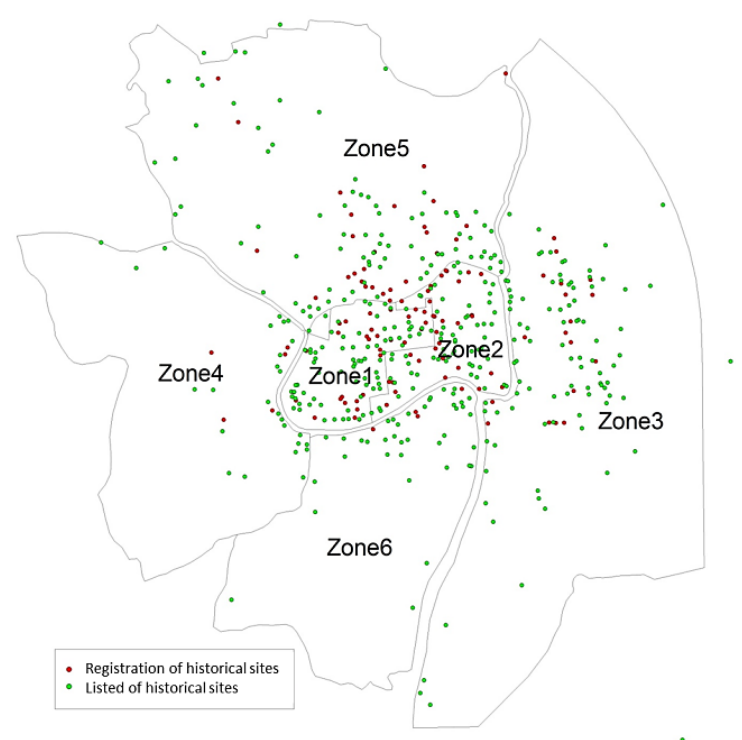

Figure 4 Distribution of historical monument sites around Ayutthaya Historical City (authors' figure, 2012)

\section{Methodology}

The methodology used in this study is divided into two parts (see Figure 5).The first part is secondary data research through books, textbooks and research documents and disaster vulnerability factors to identify possible disaster vulnerability factors and the number of HMS that might be damaged based on Geographic information system (GIS) analysis and Spatial Multicriteria Evaluation (SMCE). The study focuses on analysing the integration of GIS and Multi-criteria Decision Analysis (MCDA), which is a powerful tool to plan for disaster vulnerable HMS, because GIS provides efficient manipulation and presentation of the data and
MCDA supplies consistent ranking of the spatial vulnerability areas based on a variety of criteria. Hence, the aim of the study is to study and assess natural disaster vulnerability factors of HMS sites in the study areas of Ayutthaya based on integrating MCDA with GIS, accompanied by ranking of risk's factors for each HMS. The second part is a field survey of the flood impacts and the vulnerability values for the HMS. It shows that the previous floods have damaged the HMS in the historic city of Ayutthaya. To conserve those HMS, it is important to assess the damage in terms of environmental, external and internal damage. The levels of damage assigned, are categorized as high risk, medium risk and low risk respectively (see Figure 6). Furthermore, the historic monument values are ranked as high, medium or low values. These two factors are employed as indicators for setting the priorities of HMS conservation [19].

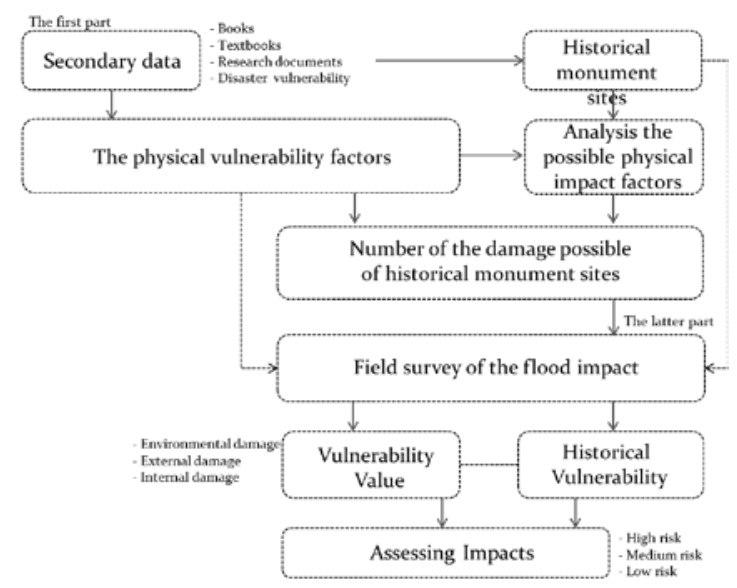

Figure 5 Methodology of study (authors' figure, 2013)

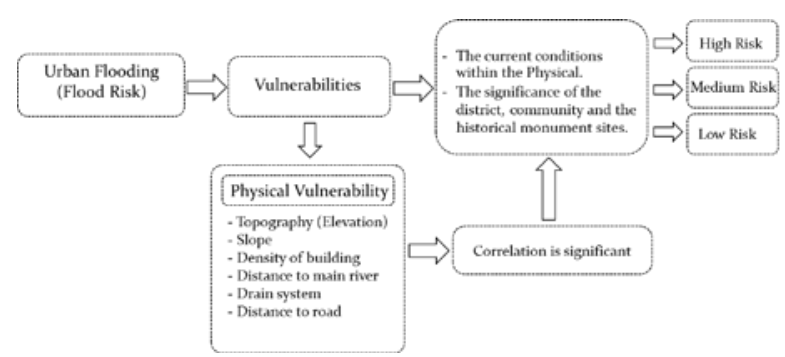

Figure 6 Framework of assessing the vulnerabilities of cultural heritage; sources (authors' figure, 2013)

\section{Results and Discussion \\ 5.1 Analysis of the possible physical impact factors}

The studies of physical vulnerability factors found that of the most crucial six factors, there are two factors that are most important in analysing the possible physical impact of flood, which are: topography and the distance from the river. The results are shown in table $3-6$. This is again classified by the degree of damage that has been specified above.

In this study 489 HMS were assessed, 294 HMS in study areas were shown to have high to extreme vulnerability. The possibilities of flood damage were assessed compared with the flood in 2011. In table 3, this study tries to summarize distances between final cluster centers in the study area in six clusters by comparing similarities and difference between groups of clusters. Table 4 is an example of the final cluster centers' sums of the two factors demonstrating the most effective as cluster 2 (o.67), cluster 6 (o.54), cluster 4 (o.49), respectively. The correlations of independent variables give significance of the risk layer to 
influence the physical damage on HMS. The results are shown in tables 4-5.

Table 3 Distances between final cluster centers

\begin{tabular}{ccccccc}
\hline Cluster & $\mathbf{1}$ & $\mathbf{2}$ & $\mathbf{3}$ & $\mathbf{4}$ & $\mathbf{5}$ & $\mathbf{6}$ \\
\hline 1 & & .483 & .318 & .221 & .500 & .452 \\
2 & .483 & & .501 & .268 & .781 & .250 \\
3 & .318 & .501 & & .365 & .282 & .313 \\
4 & .221 & .268 & .365 & & .624 & .316 \\
5 & .500 & .781 & .282 & .624 & & .581 \\
6 & .425 & .250 & .313 & .316 & .581 & \\
\hline
\end{tabular}

Table 4 Final cluster centers

\begin{tabular}{lcccccc}
\hline & \multicolumn{7}{c}{ Cluster } \\
\cline { 2 - 7 } & $\mathbf{1}$ & $\mathbf{2}$ & $\mathbf{3}$ & $\mathbf{4}$ & $\mathbf{5}$ & $\mathbf{6}$ \\
\hline Topography & .40 & .74 & .57 & .54 & .46 & .77 \\
The distance & .85 & .91 & .58 & .91 & .38 & .70 \\
from the river & & & & & & .17 \\
ZSUM & .33 & .67 & .33 & .49 & .54 \\
\hline
\end{tabular}

Table 5 The ANOVA table indicates which variables contribute the most to cluster solution

\begin{tabular}{|c|c|c|c|c|c|c|}
\hline & \multicolumn{2}{|c|}{ Cluster } & \multicolumn{2}{|c|}{ Error } & \multirow[b]{2}{*}{$\mathbf{F}$} & \multirow[b]{2}{*}{ Sig. } \\
\hline & $\begin{array}{c}\text { Mean } \\
\text { Square }\end{array}$ & df & $\begin{array}{c}\text { Mean } \\
\text { Square }\end{array}$ & df & & \\
\hline Topography & 1.525 & 5 & .006 & 483 & 246.437 & .000 \\
\hline $\begin{array}{l}\text { The distance } \\
\text { from the river }\end{array}$ & 3.274 & 5 & .005 & 483 & 620.174 & .000 \\
\hline ZSUM & 2.199 & 5 & .003 & 483 & 663.003 & .000 \\
\hline
\end{tabular}

Table 6 Number of cases in each cluster

\begin{tabular}{lccc}
\hline Cluster & Total & ZSUM \\
\hline & 1 & 70 & 0.33 \\
& 2 & 58 & 0.67 \\
& 3 & 93 & 0.33 \\
& 4 & 128 & 0.49 \\
& 5 & 32 & 0.17 \\
Valid & 6 & 108 & 0.54 \\
Missing & & 489 & \\
\hline
\end{tabular}

\subsection{Number of possible damaged historical monument sites in each cluster}

The study assessed HMS damage by the flood in 2011, from which a vulnerability value of historical monument sites around Ayutthaya Historical City can be obtained. Classification of the vulnerability value groups, found that most crucial groups are six groups which are extremely high (cluster 2), very high (cluster 6), high (cluster 4), medium (cluster 3), low (cluster 1) and very low (cluster 6).

The results of the number of HMS in each cluster defined for Vulnerability to damage value of sites around Ayutthaya Historical City are shown in figure 7-8.

In this study 489 HMS were assessed. 294 of the HMS in the study areas were classified as extremely high ( 58 of HMS), very high (108 of HMS) or high (128 of HMS) vulnerability, and were therefore the focus of the study. For the remaining 195 HMS damage assessment was carried out considering the method described (see Figure 7-8).

\begin{tabular}{|c|c|c|c|c|c|c|c|c|c|c|c|}
\hline \multirow[t]{2}{*}{ Vulnerability Value } & \multicolumn{3}{|c|}{$\begin{array}{c}\text { Registation } \\
\text { of HMS (zones) }\end{array}$} & \multirow[t]{2}{*}{ Total } & \multicolumn{5}{|c|}{ Listed of HMS(zones) } & \multirow[t]{2}{*}{ Total } & \multirow[t]{2}{*}{$\begin{array}{l}\text { Grand } \\
\text { Total }\end{array}$} \\
\hline & 1 & 23 & 3456 & & 1 & 23 & 45 & 50 & 6 & & \\
\hline 1. ExtremelyHigh & o & $1 c$ & $\begin{array}{llll}0 & 1 & 1 & 0\end{array}$ & 3 & o & 128 & 41 & 193 & 3 & 55 & 58 \\
\hline 2. Very High & 1 & 28 & $\begin{array}{llll}8 & 1 & 14 & 2\end{array}$ & 28 & 9 & 622 & 82 & 201 & 15 & 80 & 108 \\
\hline 3. High & 4 & 64 & $\begin{array}{llll}4 & 1 & 6 & 2\end{array}$ & 23 & 16 & 1425 & 72 & 291 & 14 & 105 & 128 \\
\hline 4. Medium & 7 & 94 & $\begin{array}{llll}4 & 1 & 5 & 1\end{array}$ & 27 & 14 & 2312 & $5:$ & 5 & 7 & 66 & 93 \\
\hline 5. Low & 10 & 10 & $\begin{array}{llll}1 & 1 & 1 & 0\end{array}$ & 23 & 23 & 133 & 2 & 5 & 1 & 47 & 70 \\
\hline 6. Very Low & 8 & 2 & $\begin{array}{llll}1 & \circ & 0 & 0\end{array}$ & 11 & 13 & 70 & o & 1 & o & 21 & 32 \\
\hline Grand Total & 30 & 3018 & $\begin{array}{llll}18 & 5 & 27 & 5\end{array}$ & 115 & 75 & 6490 & 267 & 79 & to & 374 & 489 \\
\hline
\end{tabular}

Figure 7 Number of cases in each cluster; sources: by authors, 2012

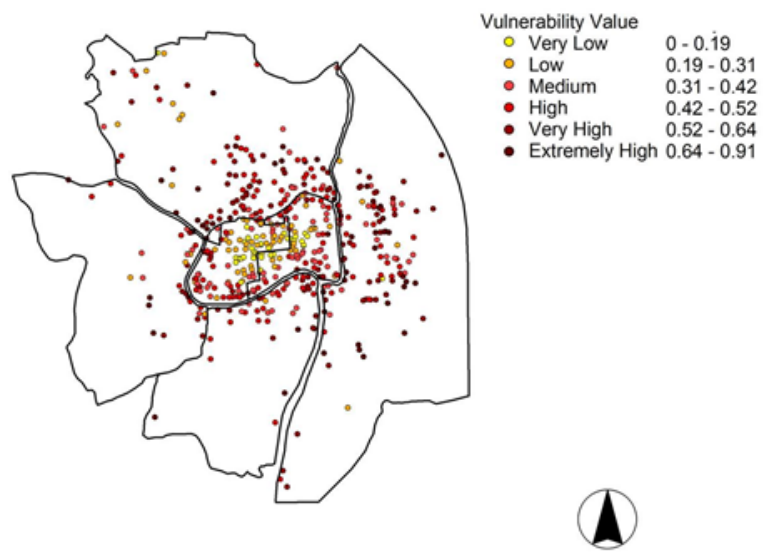

Figure 8 Vulnerability value of historical monument sites around Ayutthaya Historical City;sources: by authors, 2012

\subsection{Field survey and damage assessment}

The field survey on previous flood impacts and HMS vulnerabilities show that the previous flood has damaged the HMS in Ayutthaya. To conserve those HMS, it is important to assess the damage in terms of environmental, external and internal damage. The levels of damage: high risk, medium risk and low risk respectively, are also assigned. The results are shown in Table 7 . Furthermore, the historic monument values are ranked as high, medium or low values.

In this study 294 HMS were assessed, 84 HMS in the study area of six zones were assessed as damaged by flood in 2011 and are shown in figure 9 [19]. For the remaining 210 HMS damage assessment was carried out considering the limitations of the historic monument sites survey of damage, and some HMS were assigned to undertake renovation. The field survey of flood impacts in Ayutthaya on October - December, 2011 and drainage of moisture in the soil needs time to prevent damage to the structure of the historic monument sites.

Table 7 Assessing impacts of flood

\begin{tabular}{ccccc}
\hline Cluster score & $\begin{array}{c}\text { High Risk } \\
(181-240) \\
21.67^{-}\end{array}$ & $\begin{array}{c}\text { Med Risk } \\
(121-180)\end{array}$ & $\begin{array}{c}\text { Low Risk } \\
\left(60^{-}\right.\end{array}$ & $\begin{array}{c}\text { Total } \\
\text { (site) }\end{array}$ \\
& $29.19(\%)$ & $21.66(\%)$ & $120) 6.67^{-}$ & \\
\hline Damage site & 7 & 31 & $46(\%)$ & 84 \\
Average & 2.14 .29 & 146.77 & 96.74 & 125 \\
Min & 190 & 130 & 60 & 60 \\
Max & 240 & 180 & 120 & 240 \\
\hline
\end{tabular}

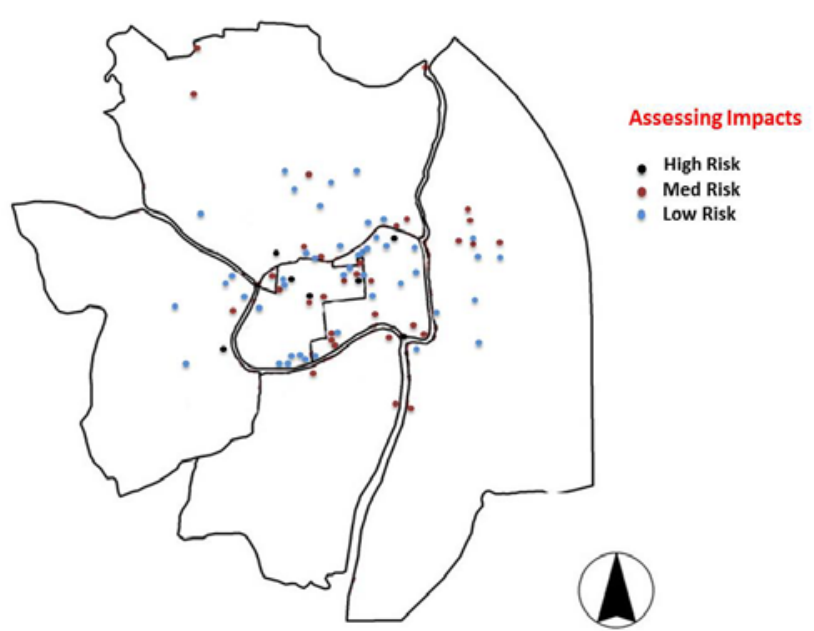

Figure 9 Assessing impacts of flood (authors' figure, 2012) 


\section{Conclusion}

The results of this research indicated that there are important elements for both the composition and configuration of possible physical impact of flood disasters and field surveys. The description of the quantitative relationships of the six disaster vulnerability factors with the urban flood disaster, found two factors that are most important to analysing the possible physical impact of flood: topography and the distance from the river. This research expands our scientific understanding of the effects of flood disaster on urban cultural heritage and HMS. The modeled possible physical flood impacts are quite similar to field survey results of HMS.

These results have important theoretical and management implications. Urban planners and Urban Architects attempting to mitigate the impact of flood disaster on urban cultural heritage can gain insights into the importance of the priorities of historic monument site conservation and renovation.

Our results are consistent with previous research assessing the impact and value of HMS. It is important to assess the damage in terms of environmental, external and internal damage. The levels of damage; high risk, medium risk and low risk respectively, are also assigned [7]. Furthermore, the historic monument values are ranked as high (Ayutthaya historical city), medium (registered) and low values (on the list) [12-13]. These two factors are employed as indicators for setting the priorities of historic monument site conservation.

\section{Acknowledgements}

The authors would like to express their sincere thanks to the anonymous reviewers for their constructive suggestions, comments, and helps. This research is supported by the Graduate School of Science and Engineering, Saga University, Japan and The Fine Arts Department, Thailand. Moreover, we would also like to thank $\mathrm{Mr}$.Manat Srivanitand Mrs. Tuti Agustin for their help providing and sharing their experiences.

\section{References}

[1] Unesco.Managing Disaster Risks for World Heritage, June 2010.

[2] The World Bank.THAI FLOOD 2011 Rapid Assessment for Resilient Recovery and Reconstruction Planning, 2012.

[3] http://www.preventionweb.net/english/countries/statistics/index.php?cid=17 0Accessed 11 March 2013.

[4] The World Bank. Climate Change Impact and Adaptation Study for Bangkok Metropolitan Region, March 2009.

[5] UNDP, Reducing Disaster Risk a challenge for development. A Global Report,United Nations Development Programme Bureau for Crisis Prevention and Recovery, 2004

[6] Cees van Westen, Guide book Session 5: Vulnerability assessment, 2009.

[7] Kasperson, J.X., Kasperson, R.E., Turner, B.L. II, Schiller, A.M.D., Hsieh, W. , "Vulnerability to global environmental change",in Kasperson, 2005; pp.245-85.

[8] Shook G. An Assessment of Disaster Risk and its Management in Thailand. Disasters 1997; 21(1):77-88.

[9] Saltbones OA. Public Health Guide for Emergencies. Indonesia after the earthquake that hit Jave - May 2006: International Federation of Red Cross and Red Crescent Societies; 2006, p. 26-43.

[10] Sirilux Mongkonkerd, Siyanee Hirunsalee, Hidehiko Kanaegae, Chaweewan Denpaiboon. Comparison of direct monetary flood damage in 2011 to pilar house and non-pillar house in Ayuthhaya, Thailand.Procedia Environmental Sciences, volume 17 (2013) 327-336.

[11] UNISDR. Terminology on Disaster Risk Reduction. Retrieved on July 2012, from:http://www.unisdr.org/files/7817_UNISDR Terminology English.pdf.
[12] Chaweewan Denpaiboon ,Manat Srivanit,Hedeiko Kanegae. New Approach of improvement "People empowering for disasterprevention" A Case Study of Ayutthaya the word Heritage Area in Thailand, 2009

[13] Edoardo A.C. Costantini, Giovanni L'Abate. The soil cultural heritage of Italy: Geodatabase, maps, and pedodiversity evaluation, 2009.

[14] C. Kubal, D. Haase, V. Meyer, S. Scheuer. Integrated urban flood risk assessment - adapting a multicriteria approach to acity, 2009.

[15] Robert Jelínek, Maureen Wood and Javier Hervas. Risk Mapping of Flood Hazards in New Member States, 2007.

[16] White, I. The Absorbent City: urban form and flood risk management. Proceedings of the Institute of Civil Engineers: Urban Design and Planning 161,2008: 151-161

[17] Office of Fine Art Department. Renovation of Master Plan of Phanakhon Sri Ayutthaya Province Project. Bangkok: AS 3D co.,1994.

[18] Fine Art Department, Ministry of Culture, The survey of Cultural Heritage, 2010.

[19] Wittaya Daungthima, Hokao Kazunori. Assessing the flood impacts and the cultural properties vulnerabilities in Ayutthaya, Thailand. Procedia Environmental Sciences, volume 17 (2013) 739-748. 